\title{
EFEKTIVITAS METODE COOPERATIF LEARNING DAN JIG SAW LEARNING TERHADAP BELAJAR SISWA
}

\author{
Savitaria \\ Magister Teknologi Pembelajaran \\ Pascasarjana IKIP PGRI Jember, Indonesia \\ e-mail: savitaria83@gmail.com
}

\begin{abstract}
ABSTRAK
Hasil belajar merupakan puncak dari segenap proses kegiatan belajarmengajar, karena sebagai bagian dari tolak ukur keberhasilan Pembelajar dan Pengajar melalui berbagai pola dan metode pembelajaran dalam kurun waktu tertentu. Hal tersebut untuk mampu menjadi pedoman dan kerangka proses kegiatan belajar mengajar (KBM) selanjutnya.

Hasil belajar juga dipengaruhi oleh metode dari pengajar kepada peserta didik berikut umpan-baliknya. Berbagai jenis metode pembelajaran yang selama ini menjadi formulasi pembelajaran salah satunya adalah Jig Saw Learning, metode ini merupakan strategi yang menarik untuk digunakan jika materi yang akan dipelajari dapat dibagi menjadi beberapa bagian dan materi tersebut tidak mengharuskan urutan penyampaian kelebihan strategi ini adalah melibatkan seluruh siswa dalam belajar dan sekaligus mengajarkan kepada orang lain.

Penerapan metode ini dalam berbagai mata pelajaran yang dapat di implementasikannya dengan daya dukung dan perangkat seperti Silabus, Pelaksanaan Pelaksanan Pembelajaran (RPP), Lembar Kegiatan Siswa (LKS), Tes formatif, dan Validitas Tes. Dalam kajian ini penulis melakukan penelitian sejauhmana efektifitas metode Jig Saw Learning diterapkan dalam pelajaran Bahasa Indonesia dengan mengkomparasikan teoritis dengan penerapan metode, bukan hanya pada hasil belajar, namun juga pada pemahaman dan pengusaan siswa terhadap materi pelajaran.
\end{abstract}

Keywords: Cooperatif Learning, Jig Saw, hasil belajar 
Efektivitas metode cooperatif learning dan jig saw learning terhadap belajar siswa

\section{Pendahuluan}

Berbicara masalah pendidikan tidak terlepas dari metode pembelajaran sebagai langkah awal menuju ketuntasan dalam proses belajar mengajar. Hal tersebut merupakan suatu landasan penting yang diharapkan sesuai dangan aturan-aturan yang dikeluarkan oleh Departemen Pendidikan Nasional (Depdiknas) maupun Badan Standar Nasional Pendidikan (BSNP), terutama bagi para tenaga pendidik, yang secara umum mengharapkan keberhasilan dalam mencetak insan-insan yang berkualitas.

Ada persepsi umum yang sudah berakar dalam dunia pendidikan dan juga sudah menjadi harapan masyarakat. Persepsi umum ini menganggap bahwa sudahmerupakan tugas guru untuk mengajar dan menyadari siswa dangan muatan-muatan informasi dan pengetahuan. Guru perlu bersikap atau setidaknya dipandang oleh siswa sebagai yang mahatahu dan sumber informasi. Siswa belajar dalam situasi yang membebani dan menakutkan karena dibayangi oleh tuntutan-tuntutan mengejar nilai-nilai tes dan ujian yang tinggi sesuai standar ketuntasan minimal. ${ }^{2}$

Hal ini perlu adanya perubahan paradigma dalam menelaah proses belajar siswa dan interaksi antara siswa dan guru. Sudah seyogyanya kegiatan belajar mengajar juga lebih mempertimbangkan siswa. Siswa bukanlah sebuah botol kosong yang bisa diisi dangan muatan-muatan informasi apa saja yang dianggap perlu oleh guru. Selain itu, alur proses belajar tidak harus berasal dari guru menuju siswa. Siswa bisa juga saling mengajar dangan sesama siswa yang lainnnya. Bahkan, banyak penelitian

1 Departemen Pendidikan Nasional, 2006, Kurikulum SMA. Jakarta: Departemen Pendidikan Nasional, hlm. 25

2 Dona, Maria Marta dkk, 2014, "Pengaruh Media Animasi dan Kemampuan Awal Siswa SMA Karya Terhadap Hasil Belajar Sistem Gerak Manusia". Universitas Tanjungpura Pontianak. Artikel Penelitian (online) 
menunjukkan bahwa pengajaran oleh rekan sebaya (peer teaching) ternyata lebih efektif daripada pengajaran oleh guru. Sistem pengajaran yang memberi kesempatan kepada anak didik uhtuk bekerjasama dangan sesame siswa dalam tugas-tugas yang terstruktur disebut sebagai sistem "pembelajaran gotong royong" atau cooperative learning. Dalam sistem ini, guru bertindak sebagai fasilitator.

Ada beberapa alasan penting mengapa sistem pengajaran ini perlu dipakai lebih Sering di sekolah-sekolah. Sesungguhnya, bagi guru-guru di negeri ini metode gotong royong tidak terlampau asing dan mereka telah sering menggunakannya dan mengenalnya sebagai metode kerja kelompok. Memang tidak bisa disangkal bahwa banyak guru telah sering menugaskan para siswa untuk bekerja dalam kelompok.

Tetapi, metode kerja kelompok sering dianggap kurang efektif. Berbagai sikap dan kesan negative memang bermunculan dalam pelaksanaan metode kerja kelompok. Jika kerja kelompok tidak berhasil, siswa cenderung saling menyalahkan. Sebaliknya jika berhasil, muncul perasaan tidak adil. Siswa yang pandai/rajin merasa rekannya yang kurang mampu telah membonceng pada hasil kerja mereka. Akibatnya, metode kerja kelompok yang seharusnya bertujuan mulia, yakni menanamkan rasa persaudaraan dan kemampuan bekerja sama, justru bisa berakhir dangan ketidakpuasaan dan kekecewaan. Bukan hanya guru dan siswa yang merasa pesimis mengenai penggunaan metode kerja kelompok, bahkan kadang-kadang orang tua pun merasa was-was jika anak mereka dimasukkan dalam satu kelompok dangan siswa lain yang dianggap kurang seimbang. ${ }^{3}$

\footnotetext{
${ }^{3}$ Syaiful Bahri Djamarah, 2000. Prestasi Belajar dan Kompetensi Guru. Surabaya: Usaha Nasional. 118
} 
Berbicara tentang hasil belajar, beberapa pakar pendidikan, khususnya yang linear dangan materi bahasa Indonesia telah banyak mengkaji, baik secara eksplisit maupun implisit terutama pada tingkatketuntasan belajarsiswa pada mata pelajaran Bahasa Indonesia. Menyikapi hal tersebut diperlukan tindakan-tindakan yang strategis dalam upaya meningkatkan pemahaman siswa terhadap materi tersebut.

Pemahaman siswa dalam Mata Pelajaran Bahasa Indonesia saat ini, khususnya pada jenjang pendidikan menengah pertama (SMP/MTs) perlu diarahkan melalui pembinaan yang dituangkan dalam tujuan pengajaran bahasa Indonesia yang secara eksplisit dinyatakan dalam kurikulum. ${ }^{4}$

Di dalam istilah hasil belajar, terdapat dua unsur di dalamnya, yaitu unsur hasil dan unsur belajar. Hasil merupakan suatu hasil yang telah dicapai pebelajar dalam kegiatan belajarnya (dari yang telah dilakukan, dikerjakan, dan sebagainya), sebagaimana dijelaskan dalam Kamus Besar Bahasa Indonesia. ${ }^{5}$ Dari pengertian ini, maka hasil belajar adalah penguasaan pengetahuan atau keterampilan yang dikembangkan oleh mata pelajaran, lajimnya ditunjukkan dangan nilai tes atau angka nilai yang diberikan oleh guru.

Belajar itu sebagai suatu proses perubahan tingkah laku, atau memaknai sesuatu yang diperoleh. Akan tetapi apabila kita bicara tentang hasil belajar, maka hal itu merupakan hasil yang telah dicapai oleh siswa. Istilah hasil belajar mempunyai hubungan yang erat kaitannya dangan prestasi belajar. Sesungguhnya sangat sulit untuk membedakan pengertian prestasi belajar dangan hasil belajar.

\footnotetext{
${ }^{4}$ Iskan darwassid dan Dadang Sunendar, 2013, Strategi Pembelajaran Bahasa. Bandung: PT Remaja Rosdakarya, Hlm. 17

${ }^{5}$ Poer, Wodarminto, 1991, Kamus Umum Bahasa Indonesia, Jakarta:Bina Ilmu. Hlm. 787
} 
Ada yang berpendapat bahwa pengertian hasil belajar dianggap sama dangan pengertian prestasi belajar. Akan tetapi lebih dahulu sebaiknya kita simak pendapat yang mengatakan bahwa hasil belajar berbeda secara prinsipil dangan prestasi belajar. Hasil belajar menunjukkan kualitas jangka waktu yang lebih panjang, misalnya satu cawu, satu semester dan sebagainya. Sedangkan prestasi belajar menunjukkan kualitas yang lebih pendek, misalnya satu pokok bahasan, satu kali ulangan harian dan sebagainya.

\section{Pembahasan}

\section{A. Faktor-faktor yang Mempengaruhi Hasil Belajar}

Sejak awal dikembangkannya ilmu pengetahuan tentang perilaku manusia, banyak dibahas mengenai bagaimana mencapai hasil belajar yang efektif. Para pakar dibidang pendidikan dan psikologi mencoba mengidantifikasikan faktorfaktor yang mempengaruhi hasil belajar. Dangan diketahuinya faktor-faktor yang berpengaruh terhadap hasil belajar, para pelaksana maupun pelaku kegiatan belajar dapat memberi intervensi positif untuk meningkatkan hasil belajar yang akan diperoleh.

Secara implisit, ada dua faktor yang mempengaruhi hasil belajar anak, yaitu faktor internal dan faktor eksternal:

1. Faktor Internal

Faktor internal meliputi faktor fisiologis, yaitu kondisi jasmani dan keadaan fungsi-fungsi fisiologis. Faktor fisiologis sangat menunjang atau melatar belakangi aktivitas belajar. Keadaan jasmani yang sehat akan lain pengaruhnya dibanding jasmani yang keadaannya kurang sehat. Untuk menjaga agar keadaan jasmani tetap sehat, nutrisi harus cukup. Hal ini disebabkan, kekurangan kadar makanan akan mengakibatkan keadaan jasmani lemah yang mengakibatkan lekas mengantuk dan lelah.Faktor 
psikologis, yaitu yang mendorong atau memotivasi belajar. Faktor-faktor tersebut diantaranya:

a. Adanya keinginan untuk tahu

b. Agar mendapatkan simpati dari orang lain. Untuk memperbaiki kegagalan

c. Untuk mendapatkan rasa aman.

\section{Faktor Eksternal}

Faktor-faktor eksternal, yaitu faktor dari diri anak yang ikut mempengaruhi belajar anak, yang antara lain berasal dari orang tua, sekolah, dan masyarakat.

a. Faktor yang berasal dari orang tua

Faktor yang berasal dari orang tua ini utamanya adalah sebagi cara mendidik orang tua terhadap anaknya. Dalam hal ini dapat dikaitkan suatuteori, apakah orang tua mendidik secara demokratis, pseudo demokratis, otoriter, atau cara laisses faire. Cara atau tipe mendidik yang demikian masing-masing mempunyai kebaikannya dan ada pula kekurangannya.

Berarti orang tua melakukan kebiasaan-kebiasaan yang positif kepada anak untuk dapat diteladani. Orang tua juga selalu memperhatikan anak selama belajar baik langsung maupun tidak langsung, dan memberikan arahan-arahan manakala akan melakukan tindakan yang kurang tertib dalam belajar.

b. Faktor yang berasal dari sekolah

Faktor yang berasal dari sekolah, dapat berasal dari guru, mats pelajaran yang ditempuh, dan metode yang diterapkan. Faktor guru banyak menjadi penyebab kegagalan belajar anak, yaitu yang menyangkut kepribadian guru, kemampuan mengajarnya. Terhadap mats pelajaran, karena kebanyakan anak memusatkan perhatianya kepada yang diminati saja, sehingga mengakibatkan nilai yang diperolehnya tidak 
sesuai danganyang diharapkan. Keterampilan, kemampuan, dan kemauan belajar anak tidak dapat dilepaskan dari pengaruh atau campur tangan orang lain. Oleh karena itu menjadi tugas guru untuk membimbing anak dalam belajar.

c. Faktor yang berasal dari masyarakat

Anak tidak lepas dari kehidupan masyarakat. Faktor masyarakat bahkan sangat kuat pengaruhnya terhadap pendidikan anak. Pengaruh masyarakat bahkan sulit dikendalikan. Mendukung atau tidak mendukung perkembangan anak, masyarakat juga ikut mempengaruhi.

Selain beberapa faktor internal dan eksternal di atas, faktor yang mempengaruhi hasil belajar dapat disebutkan sebagai berikut:

1) Minat

Seorang yang tidak berminat mempelajari sesuatu tidak akan berhasil dangan baik, tetapi kalau seseorang memiliki minat terhadap objek masalah maka dapat diharakan hasilnya baik. Masalahnya adalah bagaimana seorang pendidik selektif dalam menentukan atau memilih masalah atau materi pelajaran yang menarik siswa. Berikutnya mengenai materi yang dipilih dangan metode yang menarik. Karena itu pendidik/ pengajar perlu mengenali karakteristik siswa, misalnya latar belakang sosial kemampuan, dan lain-lain.

2) Kecerdasan

Kecerdasan memegang peranan penting dalam menentukan berhasil tidaknya seserorang. Orang pada umumnya lebih mampu belajar daripada orang yang kurang cerdas. Berbagai penelitian menunjukkan hubungan yang erat antara tingkat kecerdasan dan hasil belajar di sekolah.

3) Bakat 
Bakat merupakan kemampuan bawaan sebagai potensi yang perlu dilatih dan dikembangkan agar dapat terwujud. Bakat memerlukan latihan dan pendidikan agar suatu tindakan dapatdilakukan pada masa yang akan datang. Selain kecerdasan bakat merupakan faktor yang menentukan berhasil tidaknya seseorang dalambelajar. Belajar pada bidang yang sesuai dangan bakatnya akan memperbesar kemungkinan seseorang untuk berhasil.

4) Motivasi

Motivasi merupakan salah satu determinan penting dalam belajar, para ahli sukar mendefinisikannya, akan tetapi motifasi berhubungan dangan; (a)arah perilaku; (b)kekuatan respon yakni usaha setelah belajar siswa memilih mengikuti tindakan tertentu; dan (c) ketehanan perilaku atau beberapa lama seseorang itu terus menerus berperilaku menurut cara tertentu.

Menurut Oemar Hamalik mendefinisikan motivasi adalah perubahan energi dalam diri (pribadi) seseorang yang ditandai dangan timbulnya perasaan dan reaksi untuk mencapai tujuan. ${ }^{6}$ Dalam definisi ini terdapat tiga unsur yang saling terkait yaitu: (a) motivasi dimulai dangan adanya perubahan energi dalam pribadi;(b) motivasi ditandai dangan timbulnya perasaan; (c) motivasi ditandai dangan reaksi-reaksi untuk mencapai tujuan. ${ }^{7}$

\section{B. Pengajaran Kooperatif}

Pengajaran kooperatif (Cooperatif Learning) memerlukan pendekatan pengajaran melalui penggunaan kelompok kecil siswa untuk bekerja sama dalam memaksimalkan kondisi belajar dalam mencapai tujuan belajar.

\footnotetext{
${ }^{6}$ Oemar Hamalik, 1994. Media Pendidikan. Bandung: Cipta Aditya Bakti. Hlm. 158 7Ibid., hlm. 157
} 
1. Pengertian Pembelajaran Kooperatif

Manusia adalah makhluk individual, berbeda satudangan yang lain. Karena sifatnya yang individual maka manusia yang satu membutuhkan manusia lainnya sehingga sebagai konsekuensi logisnya manusia harus menjadi makhluk sosial, makhluk yang berinteraksi dangan sesamanya. Karena satusama lain saling membutuhkan maka harus ada interaksi yang silih asih (saling menyayangi atau saling mencintai).

Pembelajaran kooperatif merupakan pembelajaran yang secara radar dan sengaja menciptakan interaksi yang sating mengasihi antar sesama siswa.

Perbedaan antar manusia yang tidak terkelola secara baik dapat menimbulkan ketersinggungan dan kesalahpahaman antar sesamanya. Agar manusia terhindar dari ketersinggungan dan kesalahpahaman maka diperlukan interaksi yang silih asuh (saling tenggang rasa). Pembelajaran kooperatif adalah pembelajaran yang secara sadar dan sengaja menciptakan interaksi yang silih asuh untuk menghindari ketersinggungan dan kesalahpahaman yang dapat menimbulkan permusuhan.

\section{Unsur Dasar Pembelajaran Kooperatif}

Pembelajaran kooperatif adalah suatu sistem yang di dalamnya terdapatelemen-elemen yang saling terkait. Adapun berbagai elemen dalam pembelajaran kooperatif adalah adanya: saling ketergantungan positif; interaksi tatap muka; akuntabilitas individual, dan keterampilan untuk menjalin hubungan antar pribadi atau keterampilan sosial yang secara sengaja diajarkan.

a. Saling ketergantungan positif

Dalam pembelajaran kooperatif, guru menciptakan suasana yangmendorong agar siswa merasa saling membutuhkan. Hubungan yang sating membutuhan inilah yang dimaksud dangan saling 
memberikan motivasi ntuk meraih hasil belajar yang optimal. Saling ketergantungan tersebut dapat dicapai melalui: saling ketergantungan pencapaian tujuan, salingketergantungan dalam menyelesaikan tugas, saling ketergantungan bahan atau sumber, saling ketergantungan peran, dan saling ketergantunganhadiah.

b. Interaksi tatap muka

Interaksi tatap muka menuntut para siswa dalam kelompok dapat saling bertatap make sehingga mereka dapat melakukan dialog, tidak hanya dangan guru, tetapi juga dangan sesama siswa. Interaksi semacam itu memungkinkan para siswa dapat saling menjadi sumber belajar sehinggasumber belajar lebih bervariasi. Interaksi semacam itu sangat penting karena ada siswa yang merasa lebih mudah belajar dari sesamanya.

c. Akuntabilitas individual

Pembelajaran kooperatif menampilkan wujudnya dalarn belajar kelompok. Meskipun demikian, penilaian ditujukan untuk mengetahuipenguasaan siswa terhadap materi pelajaran secara individual. Hasil penilaian secara individual tersebut selanjutnya disampaikan oleh guru kepada kelompok agar semua anggota kelompok mengetahui siapa anggota kelompokmengetahui siapa anggota yang memerlukan bantuan dan siapa anggota kelompok yang dapat memberikan bantuan. Nilai kelompok didasarkan atas rata-rata hasil belajar semua anggotanya, dan karena itu tiap anggota kelompok harus memberikan urunan demi kemajuan kelompok. Penilaian kelompok secara individual inilah yang dimaksudkan dangan akuntabilitas individual.

d. Keterampilan menjalin hubungan antar pribadi

Dalam pembelajaran kooperatif keterampilan sosial seperti tenggang rasa, sikap sopan terhadap teman, mengkritik ide dan bukan mengkritifk 
teman, berani mempertahankan pikiran logic, tidak mendominasi orang lain, mandiri, dan berbagai sifat lain yang bermanfaat dalam menjalin hubungan antar pribadi (interpersonal relationship) tidak hanya diasumsikan tetapi secara sengaja diajarkan. Siswa yang tidak dapat menjalin hubungan antarpribadi tidak hanya memperoleh teguran dari guru tetapi juga dari sesama siswa. ${ }^{8}$

3. Peran Guru dalam Pembelajaran Kooperatif

Pembelajaran kooperatif menuntut guru untuk berperan relatif berbeda dari pembelajaran tradisional. Berbagai peran guru dalam pembelajaran kooperatif tersebut dapat dikemukan sebagai berikut ini.

a. Merumuskan tujuan pembelajaran. Ada dua tujuan pembelajaran yang perludiperhatikan oleh guru, tujaun akademik (academic objectives) dan tujuanketerampilan bekerja same (collaborative skill objectives Tujuan akademik dirumuskan sesuai dangan taraf perkembangan siswa dan analisis tugas atau analisis konsep. Tujuan keterampilan bekerja lama meliputi keterampilan memimpin, berkomunikasi, mempercayai orang lain, dan mengelola konflik.

b. Menentukan jumlah anggota dalam kelompok belajar. Jumlah anggota dalam tiap kelompok belajar tidak boleh terlalu besar, biasanya 2 hingga 6 siswa. Ada 3 faktor yang menentukan jumlah anggota dan kelompok belajar. Ketiga faktor tersebut adalah: (1) taraf kemampuan siswa, (2) ketersediaan bahan, dan (3) ketersediaan waktu. Jumlah anggota kelompok belajar hendaknya kecil agar tiap siswa aktif menjalin kelasama menyelesaikan tugas.

c. Menetukan tempat duduk siswa. Tempat duduk siswa hendaknya disusun agar tiap kelompok dapat saling bertatap muka tetapi cukup terpisah antara kelompok yang satu dangan kelompok lainnya.

8 Nurhadi, 2004, Pembelajaran Kontekstual dan Penerapannya dalam KBK, Malang: IKIP Malang. Hlm. 61-62 
Susunan tempat duduk dapat dalam bentuk lingkaran atau berhadaphadapan.

d. Merancang bahan untuk meningkatkan saling ketergantungan positif.

Cara menyusun bahan ajar dm penggunaannya dalam suatu kegiataii pembelajaran dapat menetukan tidak hanya efektivitas pencapaian tujuan belajar siswa

e. Menjelaskan kepada siswa mengenai tujuan dan keharusan bekerja lama. ${ }^{9}$

\section{Metode Jig Saw Learning}

Metode ini merupakan strategi yang menarik untuk digunakan jika materi yangakan dipelajari dapat dibagi menjadi beberapa bagian dan materi tersebut tidak mengharuskan urutan penyampaian kelebihan strategi ini adalah melibatkan seluruh siswa dalam belajar dan sekaligus mengajarkan kepada orang lain. Langkah-langkah metode jig saw learning antara lain:

1. Pilihlah materi pelajaran yang dapat dibagi menjadi beberapa segmen (bagian).

2. Bagilah siswa menjadi beberapa kelompok sesuai dengan jumlah segmen yang ada. Jika jumlah siswa adalah 50 sementara jumlah segmen yang ada adalah 5, maka masing - masing kelompok terdiri dari 10 orang. Jika jumlah ini dianggap terlalu besar, bagi lagi menjadi 2, sehingga setiap kelompok terdiri dari 5 orang, kemudian setelah proses selesai gabungkan kedua kelompok pecahan tersebut.

3. Setiap kelompok mendapat tugas membaca dan memahami materi yang berbeda.

4. Setiap kelompok mengirimkan anggotanya kekelompok lain untuk menyampaikan apa yang telah dipelajari dikelompok lain.

${ }^{9}$ AzharArsyad,. 2014. Media pembelajaran Edisi Revisi. Jakarta: PT. Rajawali Press. Hlm. 86 
5. Kembalikan suasana kelas seperti semula kemudian tanyakan sekiranya ada persoalan - persoalan yang tidak dipecahkan dalam kelompok.

6. Sampaikan beberapa pertanyaan kepada siswa untuk mengecek pemahaman mereka terhadap materi. ${ }^{10}$

7. Perangkat dan Implementasi Metode Jig saw Learning

a. Silabus : Yaitu seperangkat rencana dan pengaturan tentang kegiatan pembelajaran pengelolahan kelas, serta penilaian hasil belajar.

b. Pelaksanaan Pelaksanan Pembelajaran (RPP) : Yaitu merupakan perangkat pembelajaran yang digunakan sebagai pedoman guru dalam mengajar dan disusun untuk tiap putaran. Masingmasing RPP berisi kompetensi dasar, indikator pencapaian hasil belajar, tujuan pembelajaran khusus, dan kegiatan belajar mengajar.

c. Lembar Kegiatan Siswa : Lembar kegiatan ini yang dipergunakan siswa untuk membantu proses. pengumpulan data hasil kegiatan belajar mengajar.

d. Tes formatif : Tes ini disusun berdasarkan tujuan pembelajaran yang akan dicapai, digunakan untuk mengukur kemampuan pemahaman konsep Bahasa Indonesia pada pokok bahasan perkembangan teknologi untuk produksi, komunikasi dan transportasi. Tes formatif ini diberikan setiap akhir putaran. Bentuk soal yang diberikan adalah pilihan guru (objektif). Sebelumnya soal-soal ini berjumlah 30 soal yang telah diujicoba, kemudian penulis mengadakan analisis butir soaltes yang telah diuji validitas dan reliabilitas pads tiap soal. Analisis ini

${ }^{10}$ MiftahulHuda. 2013. Model-Model Pengajaran dan Pembelajaran: Isu-Isu Metodis dan Paradigmatis. Yogyakarta: Pustaka Pelajar. Hlm. 59-60 
digunakan untuk memilih soal yang baik dan memenuhi syarat digunakan untuk mengambil data. Langkah-langkah analisis butir soal adalah sebagai berikut:

e. Validitas Tes : Validitas butir soal atau validitas item digunakan untuk mengetahui tingkat kevalidan masing-masing butir soal. Sehingga dapat ditentukan butir soal yang gagal dan yang diterima. Tingkat kevalidan ini dapat dihitung dengan korelasi Product Moment: ${ }^{11}$

$r_{x y}=\frac{N \sum X Y-\left(\sum X\right)\left(\sum Y\right)}{\sqrt{\left\{N \sum X^{2}-\left(\sum X\right)^{2}\right\}\left\{N \sum Y^{2}-\left(\sum Y\right)^{2}\right\}}}$

Dengan:

$\mathrm{r}_{\mathrm{xy}} \quad$ : $\quad$ Koefisien korelasi product moment

$\mathrm{N} \quad$ : Jumlah peserta tes

$\sum Y \quad: \quad$ Jumlah skor total

$\sum X \quad$ : Jumlah skor butir soal

EXY : Jumlah kuadrat skor butir soal EXY : Jumlah hasil kali skor butir soal

a. Reliabilitas

Reliabilitas butir soal dalam penelitian ini menggunakan rumus belahdua sebagai berikut:

Dengan:

$r_{11}=\frac{2 r_{1 / 21 / 2}}{\left(1+r_{1 / 21 / 2}\right)}$

Dengan : $\quad r_{11} \quad$ : Koefisien reliabilitas yang sudah disesuaikan

$r_{1 / 21 / 2} \quad$ : Korelasi antara skor-skor setiap belahan tes

11 SuharsimiArikunto, 2001, Dasar-dasar Evaluasi Pendidikan, Jakarta: Bumi Aksara. Hlm. 72 
Kriteria reliabilitas tes jika harga $\mathrm{r}_{11}$ dari perlutungan lebih besar dari harga $\mathrm{r}$ pada tabel product moment maka tes tersebut reliabel. ${ }^{12}$

b. Taraf Kesukaran

Bilangan yang menunjukkan sukar dan mudahnya suatu soal adalah indeks kesukaran. Rumus yang digunakan untuk menentukan taraf kesukaran adalah:

$$
P=\frac{B}{J S}
$$

Dengan. $\quad P \quad$ : Indeks kesukaran

B : Banyak siswa yang menjawab soal dengan benar

Js : Jumlah seluruh siswa peserta tes. ${ }^{13}$

Kriteria untuk menentukan indeks kesukaran soal adalah sebagai berikut:

- Soal dengan $\mathrm{P}=0,000$ sampai 0,300 adalah sukar

- Soal dengan $P=0,301$ sampai 0,700 adalah sedang

- Soal dengan $\mathrm{P}=0,701$ sampai 1,000 adalah mudah

c. Daya Pembeda

Daya pembeda soal adalah kemampuan suatu soal untuk membedakan antara siswa yang berkemampuan tinggi dengan siswa yang berkemampuanrendah. Angka yang menunjukkan besarnya daya pembeda disebut indeks diskriminasi. Rumus yang digunakan untuk menghitung indeks diskriminasi adalah sebagai berikut:

$$
D=\frac{B_{A}}{J_{A}}-\frac{B_{B}}{J_{B}}=P_{A}-P_{B}
$$

Dimana:

D : $\quad$ Indeks diskriminasi

${ }^{12}$ Ibid., hlm. 93

${ }^{13}$ Ibid., hlm. 208 
$\mathrm{B}_{\mathrm{A}} \quad$ : Banyak peserta kelompok atas yang menjawab dengan benar

$\mathrm{B}_{\mathrm{B}} \quad$ : Banyak peserta kelompok bawah yang menjawab dengan benar

$\mathrm{J}_{\mathrm{A}} \quad$ : Jumlah peserta kelompok atas

Јв : Jumlah peserta kelompok bawah

$P_{A}=\frac{B_{A}}{J_{A}}=$ Proporsi peserta kelompok atas yang menjawab benar.

$P_{B}=\frac{B_{B}}{J_{B}}=$ Proporsi peserta kelompok bawah yang menjawab benar. ${ }^{14}$

Kriteria yang digunakan untuk menentukan daya pembeda butir soal sebagai berikut:

- Soal dengan $D=0,000$ sampai 0,200 adalah jelek

- Soal dengan $D=0,201$ sampai 0,400 adalah cukup

- Soal dengan $\mathrm{D}=0,401$ sampai 0,700 adalah baik

- Soal dengan $\mathrm{D}=0,701$ sampai 1,000 adalah sangat baik.

1. Metode Pengumpulan Data

Data-data yang diperlukan dalam penelitian ini diperoleh melalui observasi pengolahan belajar aktif, observasi aktivitas siswa dan guru, dan tes formatif.

2. Teknik Analisis Data

Untuk mengetahui keafektifan suatu metode dalam kegiatan pembelajaran perlu diadakan analisa data. Pada penelitian ini menggunakan teknik analisisdeskriptif kualitatif, yaitu suatu metode penelitian yang bersifat menggambarkan kenyataan atau fakta sesuai dengan data yang diperoleh dengan tujuan untuk mengetahui prestasi

14Ibid., hlm. 211 
belajar yang dicapai siswa iuga untuk memperoleh respon siswa terhadap kegiatan pembelajaran serta aktivitas siswa selama proses pembelajaran.

Untuk menganalisis tingkat keberhasilan atau persentase keberhasilan siswa setelah proses belajar mengajar setiap putarannya dilakukan dengan cara memberikan evaluasi berupa soal tes tertulis pads setiap akhir putaran. Analisis ini dihitung dengan menggunakan statistik sederhana yaitu:

1. Untuk menilai ulangan atau tes formatif

Peneliti melakukan penjumlahan nilai yang diperoleh siswa, yangselanjutnya dibagi dengan jumlah siswa yang ada di kelas tersebut sehingga diperoleh rata-rata tes formatif dapat dirumuskan:

$$
\bar{X}=\frac{\sum X}{\sum N}
$$

Dengan : $\quad \bar{X}=$ Nilai rata-rata

$\sum X=$ Jumlah semua nilai siswa

$\sum \mathrm{N}=$ Jumlah siswa

2. Untuk ketuntasan belajar

Ada dua kategori ketuntasan belajar yaitu secara perorangan dan secara klasikal. Berdasarkan petunjuk pelaksanaan belajar mengajar kurikulum 1994 (Depdikbud, 1994), yaitu seorang siswa telah tuntas belajar bila telah mencapai skor $65 \%$ atau nilai 65 , dan kelas disebut juntas belajar bila di kelas tersebut terdapat $85 \%$ yang telah mencapai daya serap lebih dari atau sama dengan 65\%. Untuk menghitung persentase ketuntasan 'belajar digunakan rumus sebagai berikut:

$$
P=\frac{\sum \text { Siswa.yang.tuntas.belajar }}{\sum \text { Siswa }} \times 100 \%
$$


Data penelitian yang diperoleh berupa hasil uji coba item butir soal, data observasi berupa pengamatan pengelolaan pembelajaran kooperatif metode jig saw learning dan pengamatan aktivitas siswa dan guru pada akhir pembelajaran, dan data tes formatif siswa pada setiap siklus.

Data hasil uji coba item butir soal digunakan untuk mendapatkan tes yang betul-betul mewakili apa yang diinginkan. Data ini selanjutnya dianalisis tingkat validitas, reliabilitas, taraf kesukaran, dan daya pembeda.

Data lembar observasi diambil dari dua pengamatan yaitu data pengamatan pengelolaan pembelajaran kooperatif metode jig saw learning yang digunakan untuk mengetahui pengaruh penerapan model pembelajaran kooperatif metode jig saw learning dalam meningkatkan prestasi belajar siswa dan data pengamatan aktivitas siswa dan guru. Data tes formatif untuk mengetahui peningkatan prestasi belajar siswa setelah diterapkan pembelajaran kooperatif metode jig saw learning.

1. Analisis Item Butir Soal

Sebelum melaksanakan pengambilan data melalui instrument penelitian berupa tes dan mendapatkan tes yang baik, maka data tes tersebut diuji dan dianalisis.Uji coba dilakukan pada siswa di luar sasaran penelitian. Analisis tes yang dilakukan meliputi:

a. Validitas : Validitas butir soal dimaksudkan untuk mengetahui kelayakan tessehingga dapat digunakan sebagai instrument dalam penelitian ini. Dari perhitungan 30 soal diperoleh 10 soal tidak valid dan 20 soal valid. Hasil dari validits soal-soal dirangkum dalam tabel di bawah ini. 
Tabel 4.1. : Soal Valid dan Tidak Valid Tes Formatif Siswa

\begin{tabular}{|l|l|}
\hline Soal Valid & Soal Tidak Valid \\
\hline $\begin{array}{l}1,2,3,4,7,9,10,11,12,13,14,17,19,21, \\
23,25,26,27,28,29,30\end{array}$ & \\
\hline
\end{tabular}

b. Reliabilitas : Soal-soal yang telah memenuhi syarat validitas diuji reliabilitasnya. Darihasil perhitungan diperoleh koefisien reliabilitas $r_{11}$ sebesar 0,554. Harga ini lebih besar dari harga $r$ product moment. Untuk jumlah siswa $(\mathrm{N}=24)$ dengan $r(63 \%)$.

c. Taraf Kesukaran (P) : Taraf kesukaran digunakan untuk mengetahui tingkat kesukaran soal. Hasil analisis rnenunjukkan dari 30 soal yang diuji terdapat:

- 13 soal mudah

- 10 soal sedang

- 7 soal sukar

2. Analisis Data Penelitian Persiklus

SiklusI

a. Tahap Perencanaan

Pada tahap ini peneliti mempersiapkan perangkat pembelajaran yang terdiri dari rencana pelaksanaan pembelajaran 1, soal tes formatif I dan alatalat pengajaran yang mendukung,

b. Tahap Kegiatan dan Pelaksanaan

Pelaksanaan kegiatan belajar mengajar untuk siklus I dilaksanakan pada tanggal 05 April2019 di Kelas VIII A dengan jumlah siswa 37 siswa. Dalam hal ini peneliti bertindak sebagai guru. Adapun proses belajar mengajar mengacu pada rencana pelaksanaan pembelajaran yang telah dipersiapkan. Pengamatan (observasi) dilaksanakan bersamaan dengan pelaksaaan belajar mengajar. 
Pada akhir proses belajar mengajar siswa diberi tes formatif I dengan tujuan untuk mengetahui tingkat keberhasilan siswa dalam proses belajar irlengajar yang telah dilakukan. Adapun data hasil penelitian pada siklus I adalah sebagai berikut:

Table 4.2. : Nilai Tes Formatif Pada Siklus I

\begin{tabular}{|c|c|c|c|c|c|c|c|}
\hline $\mathrm{N}$ & Nilai & & & No & Nil & & angan \\
\hline 0 & & $\mathrm{~T}$ & $\mathrm{~T}$ & & & $\mathrm{~T}$ & TT \\
\hline 1 & 80 & $\sqrt{ }$ & & 20 & 60 & & $\sqrt{ }$ \\
\hline 2 & 70 & $\sqrt{ }$ & & 21 & 90 & $\sqrt{ }$ & \\
\hline 3 & 60 & & $\sqrt{ }$ & 22 & 60 & & $\sqrt{ }$ \\
\hline 4 & 60 & 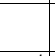 & $\sqrt{ }$ & 23 & 70 & $\sqrt{ }$ & \\
\hline 5 & 80 & $\sqrt{ }$ & & 24 & 60 & & $\sqrt{ }$ \\
\hline 6 & 80 & $\sqrt{ }$ & & 25 & 60 & & $\sqrt{ }$ \\
\hline 7 & 70 & $\sqrt{ }$ & & 26 & 70 & $\sqrt{ }$ & \\
\hline 8 & 80 & $\sqrt{ }$ & & 27 & 60 & & $\sqrt{ }$ \\
\hline 9 & 50 & & $\sqrt{ }$ & 28 & 60 &  & $\sqrt{ }$ \\
\hline 1 & 70 & $\sqrt{ }$ & & 29 & 80 & $\sqrt{ }$ & \\
\hline 1 & 70 & $\sqrt{ }$ & & 30 & 80 & $\sqrt{ }$ & \\
\hline 1 & 60 & & $\sqrt{ }$ & 31 & 80 & $\sqrt{ }$ & \\
\hline 1 & 70 & $\sqrt{ }$ & & 32 & 70 & $\sqrt{ }$ & \\
\hline 1 & 70 & $\sqrt{ }$ & & 33 & 60 & & $\sqrt{ }$ \\
\hline 1 & 70 & $\sqrt{ }$ & & 34 & 70 & $\sqrt{1}$ & \\
\hline 1 & 70 & $\sqrt{ }$ & & 35 & 60 & & $\sqrt{ }$ \\
\hline 1 & 80 & $\sqrt{ }$ & & 36 & 60 & & $\sqrt{ }$ \\
\hline 1 & 70 & $\sqrt{ }$ & & 37 & 60 & & $\sqrt{ }$ \\
\hline 1 & 70 & $\sqrt{ }$ & & & & & \\
\hline $\mathrm{J}$ & 1330 & 1 & 4 & $\mathrm{Ju}$ & 123 & 8 & 10 \\
\hline & Rata Sk & $\mathrm{rca}_{1}$ & 59, & & & & \\
\hline
\end{tabular}

Keterangan:

$\mathrm{T}$

TT

Jumlah siswa yang tuntas

Jumlah siswa yang belum tuntas

Klasikal: Belum Tuntas
Tuntas

Tidak Tuntas

23

14 
Tabel 4.3. : Rekapitulasi Hasil Tes Formatif Siswa Pada Siklus I

\begin{tabular}{|l|l|l|}
\hline No & Uraian & Hasil Siklus \\
\hline 1 & Nilai rata-rata tes formatif & 69,18 \\
2 & Jumlah siswa yang tuntas belajar & 23 \\
3 & Persentase ketuntasan belajar & 55,18 \\
\hline
\end{tabular}

Dari tabel di atas dapat dijelaskan bahwa dengan menerapkan pembelajaran kooperatif metode jig saw learning diperoleh nilai rata-rata prestasi belajar siswa adalah 69,18 dan ketuntasan belajar mencapai 23 siswa dari 24 siswa sudah tuntas belajar. Hasil tersebut menunjukkan bahwa pada siklus pertama secara klasikal siswa belum tuntas belajar, karma siswa yang memperoleh nilai >65 hanya sebesar 55,18 \% lebih kecil dari persentase ketuntasan yang dikehendaki yaitu sebesar 75\%. Hal ini disebabkan karma siswa masih baru dan asing terhadap metode baru yang diterapkan dalam proses belajar mengajar.

c. Refleksi

Dalam pelaksanaan kegiatan belajar mengajar diperoleh informasi dari hasil pengamatan sebagai berikut: (1) Guru kurang baik dalam memotivasi siswa dan dalam menyampaikan tujuan pembelajaran, (2). Guru kurang baik dalam pengelolaan waktu. Dan (3) Siswa kurang begitu antusias selama pembelajaran berlangsung.

\section{d. Refisi}

Pelaksanaan kegiatan belajar mengajar pada siklus I ini masih terdapat kekurangan, sehingga perlu adanya refisi untuk dilakukan pada siklus berikutnya : (1). Guru perlu lebih terampil dalam memotivasi siswa dan lebih jelas dalam menyampaikan tujuan pembelajaran. Dimana siswa diajak untuk terlibat langsung dalam setiap kegiatan yang akan dilakukan. (2) Guru perlu mendistribusikan waktu secara baik dengan menambahkan informasi-informasi yang dirasa perlu dan memberi 
catatan. Dan (3) Guru hares lebih terampil dan bersemangat dalam memotivasi siswa sehingga siswa bisa lebih antusias.

1. Siklus II

a. Tahap perencanaan

Pada tahap ini peneliti mempersiapkan perangkat pembelajaran yang terdiri dari rencana pelaksanaan pembelajaran 2, soal tes formatif II dan alatalat pengajaran yang mendukung.

b. Tahap kegiatan dan pelaksanaan

Pelaksanaan kegiatan belajar mengajar untuk siklus II dilaksanakan pada tanggal 05 April2019di KelasVIIIA MTs. Syirkah Salafiyah dengan jumlah siswa 37 siswa. Dalam hal ini peneliti bertindak sebagai guru. Adapun proses belajar mengajar mengacu pada rencana pelajaran dengan memperhatikan revisi pada siklus I, sehingga kesalah atau kekurangan pada siklus I tidak terulang lagi pada siklus II. Pengamatan (observasi) dilaksanakan bersamaan dengan pelaksanaan belajar mengajar.

Pada akhir proses belajar mengajar siswa diberi tes formatif II dengan tujuan untuk mengetahui tingkat keberhasilan siswa dalam proses belajar mengajar jig saw telah dilakukan. Instrument yang digunakan adalah tes formatif II.:kupon data hash penelitian pads siklus II adalah sebagai berikut.

Table 4.4. : Nilai Tes Formatif Pada Siklus II

\begin{tabular}{|c|c|c|c|c|c|c|c|}
\hline \multirow{2}{*}{$\begin{array}{l}\text { No. } \\
\text { Urut }\end{array}$} & \multirow{2}{*}{ Nilai } & \multicolumn{2}{|c|}{ Keteran } & \multirow[t]{2}{*}{ No } & \multirow[t]{2}{*}{ Nil } & \multicolumn{2}{|c|}{ Keterangan } \\
\hline & & $\mathrm{T}$ & $\mathrm{T}$ & & & $\mathrm{T}$ & TT \\
\hline & 90 & $\sqrt{ }$ & & 20 & 70 & $\sqrt{ }$ & \\
\hline 2 & 80 & $\sqrt{ }$ & & 21 & 90 & $\sqrt{ }$ & \\
\hline 3 & 70 & $\sqrt{ }$ & & 22 & 70 & $\sqrt{ }$ & \\
\hline 4 & 70 & $\sqrt{ }$ & & 23 & 90 & $\sqrt{ }$ & \\
\hline 5 & 80 & $\sqrt{ }$ & & 24 & 60 & & $\sqrt{ }$ \\
\hline 6 & 80 & $\sqrt{ }$ & & 25 & 70 & $\sqrt{ }$ & \\
\hline 7 & 80 & $\sqrt{1}$ & & 26 & 60 & & $\sqrt{ }$ \\
\hline 8 & 70 & $\sqrt{1}$ & & 27 & 70 & $\sqrt{ }$ & \\
\hline 9 & 60 & & $\sqrt{ }$ & 28 & 80 & $\sqrt{ }$ & \\
\hline
\end{tabular}




\begin{tabular}{|c|c|c|c|c|c|c|c|}
\hline 10 & 80 & $\sqrt{ }$ & & 29 & 80 & $\sqrt{ }$ & \\
\hline 11 & 80 & $\sqrt{ }$ & & 30 & 80 & $\sqrt{ }$ & \\
\hline 12 & 70 & $\sqrt{ }$ & & 31 & 80 & $\sqrt{ }$ & \\
\hline 13 & 70 & $\sqrt{ }$ & & 32 & 70 & $\sqrt{ }$ & \\
\hline 14 & 80 & $\sqrt{ }$ & & 33 & 60 & & $\sqrt{ }$ \\
\hline 15 & 70 & $\sqrt{ }$ & & 34 & 70 & $\sqrt{ }$ & \\
\hline 16 & 70 & $\sqrt{ }$ & & 35 & 60 & & $\sqrt{ }$ \\
\hline 17 & 80 & $\sqrt{ }$ & & 36 & 60 & & $\sqrt{ }$ \\
\hline 18 & 70 & $\sqrt{ }$ & & 37 & 70 & $\sqrt{ }$ & \\
\hline 19 & 80 & $\sqrt{1}$ & & & & & \\
\hline Juml & 1430 & 1 & 1 & $\mathrm{Ju}$ & 129 & 1 & 5 \\
\hline \multicolumn{8}{|c|}{$\begin{array}{l}\text { Jumlah Skor Maksimal Ideal } 3700 \\
\text { Juinlah Skor Tercapai } 2720 \\
\text { Rata-Rata Skor Tercapai 73, } 51\end{array}$} \\
\hline
\end{tabular}

Keterangan:

$\mathrm{T}$

TT

Jumlah siswa yang tuntas

Tuntas

Jumlah siswa yang belum tuntas

Klasikal

Tidak Tuntas

31

6

Belum Tuntas 
Tabel 4.5. : Rekapitulasi Hasil Tes Formatif Siswa Pada Siklus II

\begin{tabular}{|l|l|l|}
\hline No & Uraian & Hasil Siklus \\
\hline 1 & Nilai rata-rata tes formatif & 73,51 \\
2 & Jumlah siswa yang tuntas belajar & 31 \\
3 & Persentase ketuntasan belajar & 75,00 \\
\hline
\end{tabular}

Dari Label di atas diperoleh nilai rata-rata prestasi belajar siswa adalah 73,51 dan ketuntasan belajar mencapai $75,00 \%$ atau ada 31 siswa dari 37 siswa sudah tuntas belajar. Hasil ini menunjukkan bahwa pada siklus II ini ketuntasan belajar secara klasikal telah mengalami peningkatan sedikit lebih baik dari sikius I. Adanya peningkatan hasil belajar siswa ini karena siswa yang pandai mambantu siswa yang kurang mampu dalam mata pelajaran yang mereka pelajari. Disamping itu adanya kemampuan guru yang mulai meningkat dalam proses belajar mengajar.

c. Refleksi

Dalam pelaksanaan kegiatan belajar diperoleh informasi dari hasil pengamatan sebagai berikut:

1) Memotivasi siswa

2) Membimbing siswa merumuskan kesimpulan/menemukan konsep.

3) Pengelolaan waktu.

\section{Konklusi}

a. Ketuntasan Hasil belajar Siswa

Melalui hasil peneilitian ini menunjukkan bahwa pembelajaran kooperatif metode jig saw learningmemiliki dampak positif dalam meningkatkan prestasi belajar siswa. Hal ini dapat dilihat dari semakin mantapnyapemahaman dan penguasaan siswa terhadap materi yang telah disampaikan guru selama ini (ketuntasan belajar meningkat dari siklus I 
dan II) yaitu masing-masing 55,18 \% dan 73,51 \%. Pada siklus II ketuntasan belajar siswa secara klasikal telah tercapai.

b. Kemampuan Guru dalam Mengelola Pembelajaran

Berdasarkan analisis data, diperoleh aktivitas siswa dalam proses pembelajaran kooperatif metode jig saw learning dalam setiap siklus mengalami peningkatan. Hal ini berdampak positif terhadap peningkatan prestasi belajar siswa dan penguasaan materi pelajaran yang telah diterima selamaini, yaitu dapat ditunjukkan dengan meningkatnya nilai rata-rata siswa pada setiap siklus yang terus mengalami peningkatan.

2. Aktivitas Guru dan Siswa Dalam Pembelajaran

Untuk aktivitas guru selama pembelajaran telah melaksanakan langkahlangkah pembelajaran kooperatif metode jig saw learning dengan baik. Hal ini terlihat dari aktivitas guru yang muncul di antaranya aktivitas membimbing dan mengamati siswa dalam mengerjakan kegiatan, menjelaskan materi yang tidak dimengerti siswa, memberi umpan balik/ evaluasi Tanya jawab, dimana prosentasi untuk aktivitas diatas cukup besar pengaruhnya.

\section{Kesimpulan}

Ketuntasan Hail belajar Siswa melalui hasil penelitian pembelajaran kooperatif metode jig saw learning memiliki dampak positif dalam meningkatkan prestasi belajar siswa. Hal ini dapat dilihat dari semakin mantapnyapemahaman dan penguasaan siswa terhadap materi yang telah disampaikan guru selama ini (ketuntasan belajar meningkat dari siklus I dan II) yaitu masing-masing 55,18 \% dan 73,51 \%. Pada siklus II ketuntasan belajar siswa secara klasikal telah tercapai.

Berdasarkan analisis data, diperoleh aktivitas siswa dalam proses pembelajaran kooperatif metode jig saw learning dalam setiap siklus mengalami peningkatan. Hal ini berdampak positif terhadap peningkatan prestasi belajar siswa dan penguasaan materi pelajaran yang telah 
diterima selamaini, yaitu dapat ditunjukkan dengan meningkatnya nilai rata-rata siswa pada setiap siklus yang terus mengalami peningkatan.

Aktivitas Guru dan Siswa dengan menggunakan pembelajaran pembelajaran kooperatif metode jig saw learningcukup menunjukkan prosentase yang sangat baik. Hal ini terlihat dari aktivitas guru yang muncul diantaranya aktivitas membimbing dan mengamati siswa dalam mengerjakan kegiatan, menjelaskan materi yang tidak dimengerti siswa, memberi umpan balik/evaluasi Tanya jawab, dimana prosentasi untuk aktivitas diatas cukup besar pengaruhnya.

\section{Daftar Pustaka}

Arikunto, Suharsimi., 2001, Dasar-dasar Evaluasi Pendidikan, Jakarta: Bumi Aksara.

Arikunto, Suharsimi., 1993, Menegemen Mengajar Manusiawi, Jakarta:Rineksa Cipta.

Arikunto, Suharsimi, 2013, Prosedur Penelitian: Suatu Pendekatan Praktik. Jakarta: Rineka Cipta.

Arikunto, Suharsimi, 2013, Manajemen Penelitian, Jakarta: Rineka Cipta.

Arsyad, Azhar, 2009, Media pembelajaran. Jakarta: PT. Raja Grafindo Persada.

Arsyad, Azhar, 2014, Media pembelajaran Edisi Revisi. Jakarta: PT. Rajawali Press.

Aviani, Nur, 2012, Media Audio Visual. Makalah, tidak diterbitkan.

Degeng, Nyoman S, 2013, Ilmu Pembelajaran: Klasifikasi Variabel untuk Pengembangan Teori dan Penelitian. Bandung: Kalam Hidup.

Departemen Pendidikan Nasional. 2006. Kurikulum SMA. Jakarta: Departemen Pendidikan Nasional.

Djamarah, Syaiful Bahri, 2000, Prestasi Belajar dan Kompetensi Guru. Surabaya: Usaha Nasional.

Dona, Maria Marta dkk, 2014, "Pengaruh Media Animasi dan Kemampuan Awal Siswa SMA Karya Terhadap Hasil Belajar Sistem Gerak Manusia". 
Universitas Tanjungpura Pontianak. Artikel Penelitian (online) http://jurnal.untan.ac.id/index.php/jpdpb/article/download/2104 Lpdf. (diakses pada 21 Maret 2016).

Ghozali, Imam, 2005, Analisis dengan Program SPSS, Semarang: Balai Penerbit -UNDIP.

Hamalik, Oemar, 1994, Media Pendidikan, Bandung: Cipta Aditya Bakti.

Huda, Miftahul, 2013, Model-Model Pengajaran dan Pembelajaran: Isu-Isu Metodis dan Paradigmatis. Yogyakarta: Pustaka Pelajar.

Iskandarwassid dan Dadang Sunendar, 2013, Strategi Pembelajaran Bahasa. Bandung: PT Remaja Rosdakarya.

Noor, Juliansyah, 2011, Metodologi Penelitian: Skripsi, Tesis, Disertasi, dan Karya Ilmiah, Jakarta: KENCANA.

Nurhadi, 1989, Membaca Cepat dan Efektif, Bandung: CV Sinar Baru.

Nurhadi, 2004, Pembelajaran Kontekstual dan Penerapannya dalam KBK, Malang: IKIP Malang.

Poer, Wodarminto, 1991, Kamus Umum Bahasa Indonesia, Jakarta:Bina Ilmu.

Tim Gamma Science, 2007, Kamus Pintar Komplit Bahasa Indonesia, Bandung: Epsilon Grup. 